\title{
Immunoglobulin Heavy Variable 4-34
}

National Cancer Institute

\section{Source}

National Cancer Institute. Immunoglobulin Heavy Variable 4-34. NCI Thesaurus. Code C153078.

Immunog lobulin heavy variable 4-34 (123 aa, 14 kDa) is encoded by the human IGHV434 gene. This protein plays a role in antigen recognition variability. 